\title{
Oxidative stress and cardiac biomarkers in lambs affected with enzootic ataxia: the diagnostic and prognostic significance
}

\author{
Sabry M. El-Bahr ${ }^{1,2 *}$, and Wael M. El-Deeb ${ }^{3,4}$ \\ ${ }^{\prime}$ Department of Physiology, Biochemistry and Pharmacology (Biochemistry), College of Veterinary Medicine, \\ King Faisal University, Al-Ahsa, Saudi Arabia \\ ${ }^{2}$ Department of Biochemistry, Faculty of Veterinary Medicine, Alexandria University, Egypt \\ ${ }^{3}$ Department of Clinical Studies, College of Veterinary Medicine, King Faisal University, \\ Al-Ahsa, Saudi Arabia
}

${ }^{4}$ Department of Veterinary Medicine, Infectious Diseases and Fish Diseases, Faculty of Veterinary Medicine, Mansoura University, Mansoura, Egypt

EL-BAHR, S. M., W. M. EL-DEEB: Oxidative stress and cardiac biomarkers in lambs affected with enzootic ataxia: the diagnostic and prognostic significance. Vet. arhiv 87, 259-271, 2017.

\section{ABSTRACT}

Diagnostic and particularly prognostic biomarkers are essential for control of enzootic ataxia in lambs. Blood samples were collected from 32 lambs suffering from enzootic ataxia, and 15 healthy lambs as the control. Whole blood was used for estimation of hemoglobin $(\mathrm{Hb})$ in diseased and healthy animals. The harvested serum was used for estimation of copper ( $\mathrm{Cu}$ ), ceruloplasmin ( $\mathrm{Cp}$ ), selenium (Se), Malondialdehyde (MDA), reduced glutathione (GSH), superoxide dismutase (SOD), cardiac troponin I (cTnI), creatine kinase (CK) and aspartate aminotransferase (AST) levels in diseased and healthy control animals. Clinical examination revealed anemia, a fall in body temperature, an increase in heart and respiratory rates and lack of coordination in diseased animals compared to the controls. The levels of malondialdehyde, cardiac troponin I, creatine kinase and aspartate aminotransferase were significantly higher, whereas those of superoxide dismutase and reduced glutathione were significantly lower in diseased animals compared to the controls. Successfully treated lambs $(\mathrm{n}=14)$ had lower levels of cardiac troponin I, creatine kinase and malondialdehyde, but higher levels of superoxide dismutase, copper and ceruloplasmin compared to lambs with treatment failure. However, creatine kinase, superoxide dismutase and cardiac troponin I showed a high degree of accuracy in predicting treatment outcome (success vs failure). The areas under the curve for creatine kinase, superoxide dismutase and cardiac troponin I were $0 \cdot 97,0.94$ and 0.92 , respectively. Creatine kinase and superoxide dismutase showed nearly the same sensitivity and specificity (sensitivity $=94.44 \%$ vs $92.86 \%$ and specificity $=92.86 \%$ vs $93.75 \%$, respectively), and better than that of $\mathrm{cTnI}$ (sensitivity $=88.89 \%$ and specificity $=85.71 \%$ ). The current study

\footnotetext{
*Corresponding author:

Prof. Dr. Sabry M. El-Bahr, Department of Physiology, Biochemistry and Pharmacology (Biochemistry), College of Veterinary Medicine and Animal Resources, King Faisal University, Al-Ahsa, Saudi Arabia, Phone: +966 558907894 ; E-mail: sabryelbahr@hotmail.com
}

ISSN 0372-5480

Printed in Croatia 
suggests that creatine kinase, superoxide dismutase and cardiac troponin I could be used as diagnostic and prognostic biomarkers in lambs affected with enzootic ataxia.

Key words: lambs, cardiac troponin, oxidative stress, copper, trace elements

\section{Introduction}

Copper deficiency in lambs is known as swayback disease or enzootic ataxia according to regional or traditional preferences in terminology (CHALMERS, 1974). However, the term swayback refers to the neonatal or congenital form of copper deficiency, whereas the term enzootic ataxia refers to a delayed form of copper deficiency (PATTERSON et al., 1974). In the neonatal form, copper deficiency causes stillbirth, whereas in the delayed form, the lamb is normal at birth but shows clinical signs within the first 6 months of age. The causes of copper deficiency may be primary or secondary (DICK et al., 1975). In the case of primary copper deficiency, copper intake is inadequate due to low levels of copper in the feed. However, in the case of secondary copper deficiency, the feed contains adequate levels of copper but this level is not available to the tissues due to the formation of complexes with an excess of other metals (molybdenum, sulphur, iron, or zinc) (DICK et al., 1975). The main clinical signs of affected animals include decreased growth rate, anemia, ataxia, bone disorders, diarrhea, abnormal pigmentation, and poor reproductive performance (ADOGWA et al., 2005). Copper acts as a cofactor for many enzymes that are involved in critical metabolic pathways in animals (LADEFOGED and STÜRUP, 1995). Cytochrome oxidase, superoxide dismutase and catalase are the best-known copper dependent enzymes (JOHANSSON et al., 2005; ORUN et al., 2008; EL HENI et al., 2009; ALTEKIN et al., 2005). The presence of copper in the structure of superoxide dismutase and catalase indicates its antioxidant effect and the subsequent protection of vital organs against oxidative stress (JOHANSSON et al., 2005; ORUN et al., 2008; EL HENI et al., 2009). Copper deficiency participates in the pathogenesis of many heart diseases (KUTIL et al., 2010). Diagnosis of copper deficiency by measurement of copper concentration, using atomic absorption of induced coupled plasma, is complicated and time consuming. Therefore, searching for new biomarkers is essential for control of this disease. Oxidative stress biomarkers were suggested recently in Veterinary Medicine as novel prognostic and diagnostic biomarkers for many diseased conditions (EL-DEEB and EL-BAHR, 2010; ELDEEB et al., 2014; EL-DEEB and EL-BAHR, 2014; ISMAIL et al., 2015; ELJALII et al., 2015). Cardiac troponin I is a highly sensitive biomarker for diagnosis of myocardial injury in animals (WELLS and SLEEPER, 2008; FONFARA et al., 2010) and humans (REAGAN et al., 2013). Interestingly, cardiac troponin I has been successfully used for diagnosis and prognosis of different non cardiac diseases in animals (TUNCA et al., 2009; THARWAT et al., 2012; ATAOLLAHI et al., 2013; EL-DEEB and ELMOSLEMANY, 2015). The test for cardiac troponin I is available and easy to perform (BASSAND et al., 2007; SHASTRI et al., 
2012). To the authors' knowledge, no studies on the impact of oxidative stress biomarkers and cardiac troponin I on the diagnosis and prognosis of enzootic ataxia in lambs have yet been documented. Therefore, the current study aimed to investigate the prognostic and diagnostic values of cardiac troponin I and oxidative stress biomarkers together with some trace elements, such as copper and selenium, for control of enzootic ataxia in lambs.

\section{Materials and methods}

Animals. This study was conducted between January 2014 and June 2015 at the Veterinary Teaching Hospital, King Faisal University, Al-Ahsa, Saudi Arabia, where copper deficiency is very common. A total of 32 lambs with enzootic ataxia were included in this study. In addition, 15 healthy lambs without any clinical signs of disease conditions and good body condition were selected and assigned as a control. The control lambs were admitted to the teaching hospital for routine checks. All the animal procedures were performed according to the guidelines of the Animal Ethics Committee of the College of Veterinary Medicine and Animal Resources, King Faisal University, Saudi Arabia.

Sample collection and analysis. Blood samples were collected from jugular vein of both diseased and control lambs on admission. Whole blood was used for estimation of hemoglobin (DRUBKIN, 1947). Serum samples were harvested by centrifugation, and immediately frozen at $-20{ }^{\circ} \mathrm{C}$ until the time of analysis of copper, ceruloplasmin, selenium, malondialdehyde, reduced glutathione, superoxide dismutase, cardiac troponin I, creatine kinase, aspartate aminotransferase. The determination of copper and selenium was carried out by using Atomic Absorption Spectrophometer, AA-6800 model (for details see EL-BAHR and ABDELGHANY, 2015).

Standard stock solutions of copper and selenium were prepared with deionized water. Calibration curves were obtained for different concentrations of standard solutions, prepared from $1000 \mathrm{mg} / \mathrm{L}$ commercial stock solution (Merck, Darmstadt, Germany). Ceruloplasmin oxidase activity was measured in duplicate with the use of colorimetric procedures described by DEMETRIOU et al. (1974). Levels of malondialdehyde, reduced glutathione and superoxide dismutase activity were determined using commercial ELISA Kits (Cayman, USA). Cardiac troponin I was analyzed in serum samples using a pointof-care analyzer (VetScan i-STAT ${ }^{\circledR}$ 1, Abaxis, CA, USA) according to the manufacturer's instructions. Serum activities of creatine kinase, aspartate aminotransferase were determined using an automated biochemical analyzer (VetScan VS2, Abaxis, California, USA).

Statistical analysis. Due to the small size of the control group and the non-normally distributed markers in lambs affected with enzootic ataxia, differences in selected biomarkers between diseased and healthy new born lambs, and those with treatment success or failure were compared using non-parametric analysis (Wilcoxon Mann- 
Whitney) at $\mathrm{P}<0.05$. Selection of cutoff points that optimize sensitivity and specificity for each of creatine kinase, superoxide dismutase, cardiac troponin I and aspartate aminotransferase, was determined using receiver operating characteristics (ROC) analyses. The receiver operating characteristics (ROC) curves were constructed by plotting sensitivity vs 1 -specificity (false-positive rate) for all possible cut-off points for creatine kinase, superoxide dismutase, cardiac troponin I and aspartate aminotransferase. The area under the curve (AUC) indicates the overall accuracy of the tested parameter. The difference in the area under the curve (AUC) for the creatine kinase, superoxide dismutase, cardiac troponin I and aspartate aminotransferase was compared using a nonparametric method which accounts for correlations resulting from using the same samples for both tests (DELONG et al., 1988). All analyses were done using Stata version 13 (Stata Corp, College Station TX, USA).

\section{Results}

All diseased animals showed a fall in body temperature, increases in heart and respiratory rates, anemia, ataxia, diarrhea and incoordination compared to the controls. Hemoglobin concentration was significantly lower in lambs affected with enzootic ataxia $(10.6 \pm 1.0 \mathrm{~g} / \mathrm{dL})$ compared to healthy control lambs $(13.6 \pm 0.5 \mathrm{~g} / \mathrm{dL})$. The data summarized in Table 1 indicates a significant $(\mathrm{P}<0.05)$ increase in the levels of cardiac troponin I, malondialdehyde, aspartate aminotransferase and creatine kinase in diseased animals compared to controls. Conversely, there was a significant decrease in ceruloplasmin concentration, superoxide dismutase activity, reduced glutathione concentration and coper concentration in diseased animals compared to controls. Selenium concentration had not change significantly in the serum of diseased animals compared to controls (Table 1). The data presented in Table 2 describe variables, depending on treatment success or failure. The response to treatment was significantly $(\mathrm{P}<0.05)$ associated with creatine kinase, superoxide dismutase, cardiac troponin I and aspartate aminotransferase levels. Spearman's correlation ( $r$ ) analysis (Table 3 ) showed high negative $(r \geq-0 \cdot 73, \mathrm{P}<0 \cdot 001)$ correlation between treatment response and each of creatine kinase, cardiac troponin I, and aspartate aminotransferase, whereas levels of superoxide dismutase were highly and positively $(\mathrm{r} \geq 0.76, \mathrm{P}<0.001)$ correlated with treatment response. In addition, creatine kinase was positively correlated with each of serum cardiac troponin I $(r=0.73)$ and aspartate aminotransferase $(r=0.69)$. On the other hand, the values of creatine kinase were inversely correlated with the values of superoxide dismutase $(r=-0.65)$. Fig. 1 shows the receiver operating characteristic plot, which compares the area under the curve (AUC) of creatine kinase, superoxide dismutase and aspartate aminotransferase. The area under the curve (AUC) of cardiac troponin I was omitted from this plot to avoid curves overlapping because both cardiac troponin I and superoxide dismutase have the same area under the curve (AUC). 
S. M. El-Bahr and W. M. El-Deeb: New biomarkers of enzootic ataxia in lambs

Table 1. Descriptive results and univariate analysis of biochemical markers in control and lambs affected by enzootic ataxia

\begin{tabular}{|l|c|c|c|c|c|c|c|c|c|}
\hline \multirow{2}{*}{ Variables } & \multicolumn{4}{|c|}{ Control lambs $(\mathrm{n}=15)$} & \multicolumn{3}{c|}{ Diseased lambs $(\mathrm{n}=32)$} & \multirow{2}{*}{ * } \\
\cline { 2 - 12 }$n$ & Mean & Med & Min & Max & Mean & Med & Min & Max & *P \\
\hline $\mathrm{cTnI}(\mu \mathrm{g} / \mathrm{L})$ & 0.043 & 0.045 & 0.02 & 0.07 & 9.73 & 9.95 & 0.02 & 22.36 & 0.001 \\
\hline $\mathrm{Cp}(\mathrm{mg} / \mathrm{L})$ & 70.24 & 70.38 & 60.330 & 80.24 & 20.72 & 20.42 & 20.140 & 60.8 & 0.0001 \\
\hline $\mathrm{MDA}(\mu \mathrm{mol} / \mathrm{L})$ & 5.17 & 5.200 & 4.5 & 6.1 & 10.7 & 11.200 & 4.940 & 13.7 & 0.0001 \\
\hline $\mathrm{SOD}(\mathrm{U} / \mathrm{ml})$ & 161.29 & 160.30 & 152.3 & 167.30 & 105.72 & 88.69 & 85.23 & 224.36 & 0.0001 \\
\hline $\mathrm{GSH}(\mathrm{mmol} / \mathrm{L})$ & 1.61 & 1.62 & 1.48 & 1.7400 & 0.814 & 0.60 & 0.45 & 2.4500 & 0.0001 \\
\hline $\mathrm{Cu}(\mu \mathrm{mol} / \mathrm{L})$ & 12.75 & 12.56 & 11.33 & 14.250 & 1.462 & 1.360 & 0.9 & 2.3200 & 0.0001 \\
\hline $\mathrm{AST}(\mathrm{U} / \mathrm{L})$ & 84.71 & 87.23 & 66.32 & 108.23 & 238.8 & 280.26 & 88.3 & 420.1 & 0.0001 \\
\hline $\mathrm{CK}(\mathrm{U} / \mathrm{L})$ & 73.82 & 75.24 & 65.36 & 82.36 & 345.1 & 360.25 & 155.3 & 680.3 & 0.0001 \\
\hline $\mathrm{Se}(\mu \mathrm{mol} / \mathrm{L})$ & 0.83 & 0.86 & 0.71 & 0.87 & 0.78 & 0.72 & 0.71 & 0.86 & 0.7572 \\
\hline
\end{tabular}

cTnI: cardiac troponin I; Cp: ceruloplasmin; MDA: malondialdehyde; SOD: super oxide dismutase; GSH: glutathione; $\mathrm{Cu}$ : copper; AST: aspartate aminotransferase; $\mathrm{CK}$ : creatine kinase; Se: selenium. ${ }^{*} P$-value resulting from non-parametric Wilcoxon Mann-Whitney test.

Table 2. Description of variables depending on the response to treatment in lambs with enzootic ataxia

\begin{tabular}{|l|c|c|c|c|c|c|c|c|c|}
\hline \multirow{2}{*}{ Variables } & \multicolumn{4}{|c|}{ Treatment failure $(\mathrm{n}=18)$} & \multicolumn{3}{c|}{ Treatment success $(\mathrm{n}=14)$} & $* \mathrm{P}$ \\
\cline { 2 - 12 } & Mean & Med & Min & Max & Mean & Med & Min & Max & \\
\hline $\mathrm{cTnI}(\mu \mathrm{g} / \mathrm{L})$ & 16.02 & 18.36 & 0.03 & 22.36 & 1.63 & 0.054 & 0.021 & 10.3 & 0.0001 \\
\hline $\mathrm{Cp}(\mathrm{mg} / \mathrm{L})$ & 20.345 & 20.280 & 20.140 & 30.470 & 30.204 & 20.865 & 20.420 & 60.8 & 0.4201 \\
\hline $\mathrm{MDA}(\mu \mathrm{mol} / \mathrm{L})$ & 11.764 & 12.640 & 5.200 & 13.700 & 9.346 & 9.750 & 4.940 & 12.7 & 0.0027 \\
\hline $\mathrm{SOD}(\mathrm{U} / \mathrm{mL})$ & 94.76 & 87.30 & 65.23 & 124.36 & 119.8 & 101.9 & 92.6 & 223.7 & 0.0001 \\
\hline $\mathrm{GSH}(\mathrm{mmol} / \mathrm{L})$ & 0.827 & 0.600 & 0.450 & 1.72 & 0.796 & 0.590 & 0.520 & 2.45 & 0.6754 \\
\hline $\mathrm{Cu}(\mu \mathrm{mol} / \mathrm{L})$ & 1.3350 & 1.250 & 0.90 & 1.87 & 1.6243 & 1.61 & 1.21 & 2.32 & 0.0214 \\
\hline $\mathrm{AST}(\mathrm{U} / \mathrm{L})$ & 280.7 & 290.3 & 90.4 & 420.1 & 184.9 & 111.5 & 88.3 & 330.3 & 0.0202 \\
\hline $\mathrm{CK}(\mathrm{U} / \mathrm{L})$ & 453.1 & 443.3 & 190.3 & 680.3 & 206.3 & 190.2 & 155.3 & 290.3 & 0.0001 \\
\hline $\mathrm{Se}(\mu \mathrm{mol} / \mathrm{L})$ & 0.91 & 0.94 & 0.85 & 0.96 & 0.87 & 0.80 & 0.79 & 0.96 & 0.5472 \\
\hline
\end{tabular}

cTnI: cardiac troponin I; Cp: ceruloplasmin; MDA: malondialdehyde; SOD: super oxide dismutase; GSH: glutathione; $\mathrm{Cu}$ : copper; AST: aspartate aminotransferase; CK: creatine kinase; Se: selenium. *P-value resulting from non-parametric Wilcoxon Mann-Whitney test. 
Table 3. Spearmen's correlation coefficient between cardiac troponin I and each of the other cardiac biomarkers (AST, CK), oxidative stress biomarkers (MDA, GSH, SOD, TAC, NO) and trace elements $(\mathrm{Cu}, \mathrm{Se})$ and $\mathrm{Cp}$ in lambs affected with enzootic ataxia.

\begin{tabular}{|c|c|c|c|c|c|c|c|c|c|}
\hline Variables & cTnI & $\mathrm{Cp}$ & MDA & SOD & GSH & $\mathrm{Cu}$ & $\mathrm{Se}$ & AST & $\mathrm{CK}$ \\
\hline $\begin{array}{l}\mathrm{Cp} \\
(\mathrm{mg} / \mathrm{L})\end{array}$ & $* *-0.549$ & & & & & & & & \\
\hline $\begin{array}{l}\text { MDA } \\
(\mu \mathrm{mol} / \mathrm{L})\end{array}$ & $* * 0.549$ & $* * * 0.822$ & & & & & & & \\
\hline $\begin{array}{l}\text { SOD (U/ } \\
\mathrm{mL})\end{array}$ & $* *-0.525$ & **** 0.742 & $-0.725^{* * *}$ & & & & & & \\
\hline $\begin{array}{l}\mathrm{GSH} \\
(\mathrm{mmol} / \mathrm{L})\end{array}$ & $* *-0.400$ & **** 0.730 & $* *-0.691$ & $* * 0.710$ & & & & & \\
\hline $\begin{array}{l}\mathrm{Cu} \\
(\mu \mathrm{mol} / \mathrm{L})\end{array}$ & $* *-0.533$ & ****0.941 & $* * *-0.777$ & ***0.632 & ${ }^{* *} 0.679$ & & & & \\
\hline $\begin{array}{l}\mathrm{Se} \\
(\mu \mathrm{mol} / \mathrm{L})\end{array}$ & $* 0.156$ & 0.003 & 0.068 & -0.026 & ${ }^{*} 0.153$ & -0.020 & & & \\
\hline $\begin{array}{l}\text { AST } \\
(\mathrm{U} / \mathrm{L}) \\
\end{array}$ & $* * 0.568$ & *** -0.668 & $* * 0.641$ & $* * 0.633$ & $* *-0.440$ & $* *-0.624$ & ${ }^{*} 0.168$ & & \\
\hline CK (U/L) & *** 0.728 & ***** -0.768 & ****0.769 & * * -0.646 & $* *-0.490$ & ***-0.723 & "0.152 & ***0.691 & \\
\hline Outcomes & **** -0.761 & * 0.165 & * -0.143 & ***0.764 & ${ }^{*} 0.078$ & ***0.416 & ${ }^{*} 0.264$ & *** -0.729 & **** -0.816 \\
\hline
\end{tabular}

cTnI: cardiac troponin I; Cp: ceruloplasmin; MDA: malondialdehyde; SOD: super oxide dismutase; GSH: glutathione; $\mathrm{Cu}$ : copper; AST: aspartate aminotransferase; CK: creatine kinase; Se: selenium. ${ }^{*}$ Significant correlations at $\mathrm{P}<0.05 ; * *$ Significant correlations at $\mathrm{P}<0.01$ and $* * *$ Significant correlations at $\mathrm{P}<0.001$.

Data summarized in Table 4 and Fig. 1 indicate that creatine kinase, superoxide dismutase and cardiac troponin I showed high accuracy in predicting treatment response at the selected threshold ( $\mathrm{AUC}=0.97,0.94$ and 0.92 , respectively), whereas aspartate aminotransferase showed lower accuracy than creatine kinase, superoxide dismutase and cardiac troponin I at the selected threshold $(\mathrm{AUC}=0.74)$. Creatine kinase and superoxide dismutase showed nearly the same sensitivity and specificity (sensitivity $=94.44 \%$ vs $92.86 \%$ and specificity $=92.86 \%$ vs $93.75 \%$, respectively) which were better than those of cardiac troponin I (sensitivity $=88.89 \%$ and specificity $=85.71 \%)$. However, comparison of the area under the curve (AUC) indicated no significant difference between the areas under the curve (AUC) for creatine kinase, superoxide dismutase and cardiac troponin I $(\mathrm{P}=0.142)$. 
Table 4. Threshold and test characteristics of selected biomarkers for prognosis of treatment success and failure in lambs affected with enzootic ataxia.

\begin{tabular}{|l|c|c|c|c|}
\hline Parameters & Threshold & Sensitivity & Specificity & AUC $(95 \% \mathrm{CI})$ \\
\hline CK $(\mathrm{U} / \mathrm{L})$ & 192.6 & 94.44 & 92.86 & $0.97(0.84-1.00)$ \\
\hline SOD $(\mathrm{U} / \mathrm{mL})$ & 201.3 & 92.86 & 93.75 & $0.94(0.79-0.99)$ \\
\hline $\mathrm{cTn} 1(\mu \mathrm{g} / \mathrm{L})$ & 6.3 & 88.89 & 85.71 & $0.92(0.79-0.99)$ \\
\hline AST $(\mathrm{U} / \mathrm{L})$ & 290.3 & 83.33 & 57.14 & $0.74(0.57-0.89)$ \\
\hline
\end{tabular}

CK: creatine kinase; SOD: super oxide dismutase; cTnI: cardiac troponin I; AST: aspartate aminotransferase; AUC: area under the curve; CI: confidence interval.

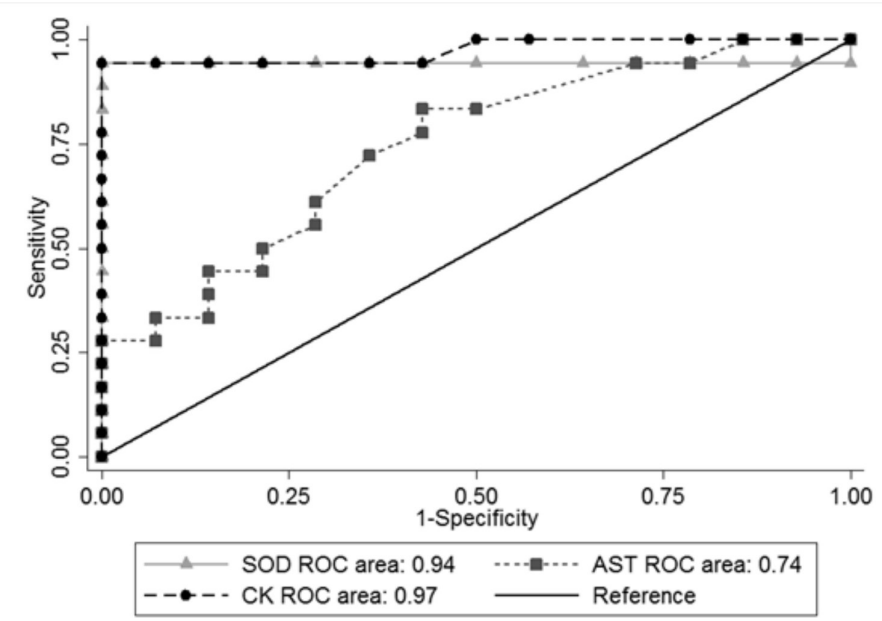

Fig. 1. Receiver operating characteristic (ROC) plot: Comparison of the AUC for SOD, CK and AST. SOD: super oxide dismutase; CK: creatine kinase; AST aspartate aminotransferase; AUC: area under the curve.

\section{Discussion}

In the current study, clinical examination revealed anemia of enzootic ataxia affected lambs compare to the controls. Anemia observed clinically was confirmed by low hemoglobin concentrations observed in the blood of lambs affected by enzootic ataxia compared to controls. Hemoglobin is an iron-containing protein, associated with oxygen transport in blood. Normal hemoglobin concentrations for most mammals are 13-15 g/L (SWENSON and REECE, 1993). The mean hemoglobin concentration in the enzootic ataxia affected lambs was significantly lower than the reference value and those of healthy control animals. Lower concentrations may be linked to copper deficiency (SANDERS 
and SANDER, 1983). Average blood copper values of $<0.5 \mu \mathrm{g} / \mathrm{mL}(7.9 \mu \mathrm{mol} / \mathrm{L})$ are a sign of severe copper deficiency in ruminants (ARTHINGTON et al., 2002; GENGELBACH et al., 1997). In the current study, the mean concentration of copper was very low in lambs affected with enzootic ataxia $(1.462 \mu \mathrm{mol} / \mathrm{L})$ compared to controls $(12.75 \mu \mathrm{mol} / \mathrm{L})$. Most of the copper in serum is presented as ceruloplasmin, which plays an essential role in the absorption and transport of iron. Therefore, $\mathrm{Cu}$ deficiency not only markedly reduces the content of ceruloplasmin but is accompanied by anemia, as mentioned above. The concentration of selenium had not changed significantly in enzootic ataxia affected lambs compared to controls. Regarding selenium, similar results have been documented in Guizhou semi-fine wool sheep on pasture in south-west China, in a karst mountain area (RONG et al., 2011).

In the current study, the elevated levels of cardiac troponin I in lambs affected with enzootic ataxia compared to healthy control animals indicated a possible myocardial injury. Cardiac troponin I is a specific and highly sensitive biomarker for heart conditions (O'BRIEN et al., 2006; WELLS and SLEEPER, 2008). Beside the increase in the level of cardiac troponin I, other non-specific biomarkers (creatine kinase, and aspartate aminotransferase ) were also increased in the serum of lambs affected with enzootic ataxia compared to healthy control animals, supporting the possibility of cardiac injury. A similar increase in these parameters was reported in lambs affected with white muscle disease (TUNCA et al., 2009; ATAOLLAHI et al., 2013). The actual mechanism of cardiac injury in lambs affected with enzootic ataxia is uncertain. However, copper deficiency participates in the pathogenesis of numerous heart diseases (KUTIL et al., 2010). In addition, the elevated serum cardiac troponin I concentration in lambs affected with enzootic ataxia may be attributed to the occurrence of anemia, which was evident in the current study. Anemia followed by hypoxia may lead to cardiac damage (FARTASHVAND et al., 2013). The prognostic accuracy of cardiac troponin I with non-primary cardiac disorders has been studied, and a positive predictive ability for cardiac troponin I for disease outcome has been well documented in humans (WANG et al., 2009) and animals (EL-DEEB and ELMOSLEMANY, 2015). However, to the best of the authors' knowledge, this is the first study to address the diagnostic and prognostic accuracy of cardiac troponin I, creatine kinase and aspartate aminotransferase in cases of enzootic ataxia in lambs. In the successfully treated lambs, cardiac troponin I, creatine kinase and aspartate aminotransferase was significantly lower than in lambs with treatment failure. In the present study, creatine kinase and cardiac troponin I (cTnI) concentrations were lower than $290.3 \mathrm{UL}^{-1}$ and lower than $10.3 \mathrm{ng}$ $\mathrm{mL}^{-1}$, respectively, in successfully treated lambs. On the other hand, 14 out of 18 lambs with treatment failure had a serum creatine kinase and cardiac troponin I concentrations higher than $400 \mathrm{UL}^{-1}$ and higher than $14.36 \mu \mathrm{g} \mathrm{L}^{-1}$, respectively. Therefore, it may be suggested that the increased serum concentrations of creatine kinase and cardiac troponin $\mathrm{I}$, over $400 \mathrm{UL}^{-1}$ and over $14 \cdot 36 \mu \mathrm{g} \mathrm{L}^{-1}$, respectively, upon initial examination, were a bad 
prognostic indicator in lambs affected with enzootic ataxia. Creatine kinase showed better sensitivity and specificity than cardiac troponin I (sensitivity $=94.44 \%$ vs $88.89 \%$ and specificity $=92.86 \%$ vs $85.71 \%$, respectively). However, comparison of the area under the curve (AUC) indicated no significant difference between the areas under the curve (AUC) for creatine kinase and cardiac troponin I $(\mathrm{P}=0.142)$. In the current study, oxidative stress was evident, as indicated by higher level of the lipid peroxidation biomarker (malondialdehyde, MDA), and stimulation of antioxidants (superoxide dismutase and reduced glutathione) to counteract the active free radicals in enzootic ataxia affected lambs. The increased concentration of malondialdehyde in the serum of lambs affected with enzootic ataxia compared with the heathy control lambs indicated the important role of copper in oxidative stability in the plasma of sheep (CHENG et al., 2011). The lower level of reduced glutathione shown in the serum of lambs affected with enzootic ataxia compared to the control lambs indicated the consumption of glutathione in the process of free radical scavenging. Superoxide dismutase is a Copper-dependent enzyme, associated functionally with copper in different tissues (McCORD and FRIDOVICH, 1969). The activities of superoxide dismutase are a sensitive indicator for diagnosing copper deficiency in ruminants, because serum values of superoxide dismutase and copper are positively correlated in cattle, camel and yaks (SHEN, 2009). A previous study (RONG et al., 2011) demonstrated a lower level of superoxide dismutase in Guizhou semi-fine wool sheep affected with copper deficiency compared to healthy control sheep. In the present study, serum superoxide dismutase SOD activities were above $92.6 \mathrm{UmL}^{-1}$ in successfully treated lambs. On the other hand, 13 out of 18 lambs with treatment failure had serum superoxide dismutase activities below $80 \mathrm{UmL}^{-1}$. Therefore, it may be suggested that the decreased serum activity of superoxide dismutase under $80 \mathrm{UmL}^{-1}$ at the initial examination was a bad prognostic indicator in lambs affected with enzootic ataxia. The increase in malondialdehyde and decrease in superoxide dismutase in the serum of lambs affected with enzootic ataxia indicated the existence of oxidative stress, mainly to cardiac tissues, as evidenced by the significant increase in specific (cardiac troponin I) and nonspecific (superoxide dismutase, aspartate aminotransferase) cardiac biomarkers in the current study. The current findings also led to the conclusion that increased serum concentration of creatine kinase, cardiac troponin I and aspartate aminotransferase, with decreased superoxide dismutase activity in lambs affected with enzootic ataxia, shed light on the possible existence of myocardial injury in diseased animals. The investigated biomarkers (creatine kinase, cardiac troponin I and superoxide dismutase) may be used as diagnostic and prognostic biomarkers in lambs affected with enzootic ataxia. Therefore, an antioxidant is recommended as supportive medicine for lambs affected with enzootic ataxia. 
S. M. El-Bahr and W. M. El-Deeb: New biomarkers of enzootic ataxia in lambs

\section{References}

ADOGWA, A., A. MUTANI, A. RAMNANAN, C. EZEOKOLI (2005): The effect of gastrointestinal parasitism on blood copper and hemoglobin levels in sheep. Can. Vet. J. 46, 1017-1021.

ALTEKIN, E., C. COKER, A. R. SISMAN, B. ONVURAL, F. KURALAY, O. KIRIMLI (2005): The relationship between trace elements and cardiac markers in acute coronary syndromes. J. Trace Elem. Med. Bio. 18, 235-242.

ARTHINGTON, J. D., J. E. RECHCIG, G. P. YOST, L. R. McDOWELL, M. D. FANNING (2002): Effect of ammonium sulfate fertilization on bahiagrass quality and copper metabolism in grazing beef cattle. J. Anim. Sci. 80, 2507-2512.

ATAOLLAHI, F., M. MOHRI, H. A. SEIFI (2013): Diagnostic value of cardiac troponin I (cTnI), creatine kinase (CK), and aspartate amino transferase (AST) in selenium deficiency in lambs. Revue Méd. Vét. 164, 207-211.

BASSAND, J. P., C. W. HAMM, D. ARDISSINO, E. BOERSMA, A. BUDAJ, F. F. AVILES, K. A. FOX, D. HASDAI, E. M. OHMAN, L. WALLENTIN, W. WIJNS (2007): Guidelines for the diagnosis and treatment of non-ST-segment elevation acute coronary syndromes. Eur. Heart J. 28, 1598-1660.

CHALMERS, G. A. (1974): Swayback (Enzootic Ataxia) in Alberta Lambs. Can. J. comp. Med. $38,111-117$.

CHENG, J., H. MA, C. FAN, Z. ZHANG, Z. JIA, X. ZHU, L. WANG (2011): Effects of different copper sources and levels on plasma superoxide dismutase, lipid peroxidation, and copper status of lambs. Biol. Trace Elem. Res. 144, 570-579.

DELONG, E. R., D. M. DELONG, D. L. CLARKE-PEARSON (1988): Comparing the areas under two or more correlated receiver operating characteristic curves: a nonparametric approach. Biometrics 44, 837-845.

DEMETRIOU, J. A., P. A. DREWES, J. B. GIN (1974): Ceruloplasmin. In: Clinical Chemistry: Principles and Techniques (Cannon, D., C. Winkelman, Eds.),, Harper and Row, Hagerstown, MD, pp. 857-864.

DICK, A. T., D. W. DEWEY, J. M. GAWTHORNE (1975): Thiomolybdates and coppermolybdenum-sulphur interaction in ruminant nutrition. J. Agric. Sci. 85, 567-568.

DRUBKIN, D. (1947): Spectrophotometric methods XIV. The crystographic and optical properities of the haemoglobin of man in comparison with those of other species. J. Biol. Chem. 164, 703-723.

EL-BAHR, S. M., A. ABDELGHANY (2015): Heavy metal and trace element contents in edible muscle of three commercial fish species, and assessment of possible risks associated with their human consumption in Saudi Arabia. J. Adv. Vet. Anim. Res. 2, 271-278.

EL-DEEB, W., S. M. EL-BAHR (2014): Acute phase proteins and oxidative stress biomarkers in water buffalo calves subjected to transportation stress. Clin. Comp. Pathol. 23, 577-582. 
EL-DEEB, W. M., A. M. ELMOSLEMANY (2015): Cardiac and oxidative stress biomarkers in Trypanosoma evansi infected camels: diagnostic and prognostic prominence. Parasitol. 142, 767-772.

EL-DEEB, W. M., S. M. EL-BAHR (2010): Investigation of selected biochemical indicators of Equine Rhabdomyolysis in Arabian horses: pro-inflammatory cytokines and oxidative stress markers. Vet. Res. Commun. 34, 677-689.

EL-DEEB, W. M., T. A. FOUDA, S. M. EL-BAHR (2014): Clinico-biochemical investigation of paratuberculosis of dromedary camels in Saudi Arabia: proinflammatory cytokines, acute phase proteins and oxidative stress biomarkers. Pak. Vet. J. 34, 484-488.

EL HENI, J., M. IMED, H. FATIMA, K. ABDELHAMID (2009): Protective effects of selenium (Se) and zinc $(\mathrm{Zn})$ on cadmium $(\mathrm{Cd})$ toxicity in the liver of the rat: Effects on the oxidative stress. Ecotox. Environ. Safety 72, 1559-1564.

ELJALII, I. M., W. M. EL-DEEB, T. A. FOUDA, A. M. ALMUJALLI, S. M. EL-BAHR (2015): Blood picture and selected oxidative stress biomarkers in dromedary camels naturally infected with Trypanosoma evansi. Int. J. Vet. Sci. Res. 1, 46-53.

FARTASHVAND, M., M. G. NADALIAN, M. SAKHA, S. SAFI (2013): Elevated serum cardiac troponin I in cattle with theileriosis. J. Vet. Int. Med. 27, 194-199.

FONFARA, S., J. LOUREIRO, S. SWIFT, R. JAMES, P. CRIPPS, J. DUKES-MCEWAN (2010): Cardiac troponin I as a marker for severity and prognosis of cardiac disease in dogs. Vet. J. 184, 334-339.

GENGELBACH, G. P., J. D. WARD, J. W. SPEARS, T. T. BROWN (1997): Effects of copper deficiency and copper deficiency coupled with high dietary iron or molybdenum on phagocytic cell function and response of calves to respiratory disease challenge. J. Anim. Sci. 75, 11121118.

ISMAIL, I. B., K. A. AL-BUSADAH, S. M. EL-BAHR (2015): Biochemical markers of oxidative stress in tissues of broiler chickens fed zinc bacitracin and ascorbic acid under hot climate. Int. J. Biol. Chem. 9, 38-45.

JOHANSSON, L., G. GAFVELIN, E. S. J. ARNER (2005): Selenocysteine in proteins-properties and biotechnological use. Biochim. Biophys. Acta 1726, 1-13.

KUTIL, B., P. OSTADAL, J. VEJVODA, J. KUKACKA, J. CEPOVA, D. ALAN, A. KRUGER, D. VONDRAKOVA (2010): Alterations in serum selenium levels and their relation to troponin I in acute myocardial infarction. Mol. Cell Biochem. 345, 23-27.

LADEFOGED, O., S. STÜRUP (1995): Copper deficiency in cattle, sheep and horses caused by excess molybdenum from fly ash: A case report. Vet. Human Toxicol. 37, 63-65.

McCORD, J. M., I. FRIDOVICH (1969): Superoxide dismutase: an enzymic function for erythrocuprein (hemocuprein). J. Biol. Chem. 244, 6049-6055.

O'BRIEN, P. J., D. E. SMITH, T. J. KNECHTEL, M. A. MARCHAK, I. PRUIMBOOM-BREES, D. J. BREES, D. P. SPRATT, F. J. ARCHER, P. BUTLER, A. N. POTTER, J. P. PROVOST, J. RICHARD, P. A. SNYDER, W. J. REAGAN (2006): Cardiac troponin I is a sensitive, specific biomarker of cardiac injury in laboratory animals. Lab. Anim. 40, 153-171. 
ORUN, I., Z. S. TALAS, I. OZDEMIR, A. ALKAN, K. ERDOGAN (2008): Antioxidative role of selenium on some tissues of $(\mathrm{Cd} 2+, \mathrm{Cr} 3+)$-induced rainbow trout. Ecotox Environ. Safe 71, $71-75$.

PATTERSON, D. S., J. A. FOULKES, D. SWEASEY, E. M. GLANCY, S. TERLECKI (1974): A neurochemical study of field cases of the delayed spinal form of swayback (enzootic ataxia) in lambs. J. Neurochem. 23, 1245-1253.

REAGAN, W. J., M. YORK, B. BERRIDGE, E. SCHULTZE, D. WALKER, S. PETTIT (2013): Comparison of cardiac troponin I and T, including the evaluation of an ultrasensitive assay, as indicators of doxorubicin-induced cardiotoxicity. Toxicol. Pathol. 41, 1146-1158.

RONG, Y., L. LI-JUAN, W. QI-WEN, D. GUO-ZHEN (2011): Copper deficiency in Guizhou semifine wool sheep on pasture in south west China karst mountain area. Afr. J. Biotechnol. 10, 17043-17048.

SANDERS, D. E., J. A. SANDER (1983): Diagnosis and management of copper deficiency in dairy cattle. Mod. Vet. Pract. 64, 63-65.

SHASTRI, A. T., S. SAMARASEKARA, H. MUNIRAMAN, P. CLARKE (2012): Cardiac troponin I concentrations in neonates with hypoxic-ischaemic Encephalopathy. Acta Paediatrica 101, 26-29.

SHEN, X. Y. (2009): Effect of nitrogenous fertilizer treatment on mineral metabolism in grazing yaks. Agric. Sci. China 8, 361-368.

SWENSON, M. J., W. O. REECE (1993): Physiological properties and cellular and chemical constituents of blood. In: Dukes' Physiology of Domestic Animals. (Swenson, M., W. O. Recee, Eds.), Cornell Univ Press, New York, pp. 22-24.

THARWAT, M., F. AL-SOBAYIL, K. AL-SOBAYIL (2012): The cardiac biomarkers troponin I and CK-MB in nonpregnant and pregnant goats, goats with normal birth, goats with prolonged birth, and goats with pregnancy toxemia. Theriogenol. 78, 1500-1507.

TUNCA, R., H. M. ERDOĞAN, M. SOZMEN, M. CITIL, A. K. DEVRIM, S. ERGINSOY, E. UZLU (2009): Evaluation of Cardiac Troponin I and Inducible Nitric Oxide Synthase Expressions in Lambs with White Muscle Disease Turk. J. Vet. Anim. Sci. 33, 53-59.

WANG, L., D. M. BUNK, H.-J. HE, K. D. COLE (2009): Removal of inhibitory effects in a serum cardiac troponin I immunoassay. Clin. Chemistry 55, 2055-2056.

WELLS, S. M., M. SLEEPER (2008): Cardiac troponins. J. Vet. Emerg. Crit. Care 18, 235-245.

Received: 26 January 2016

Accepted: 22 November 2016 


\section{EL-BAHR, S. M., W. M. EL-DEEB: Oksidacijski stres i srčani biomarkeri u janjadi oboljele od enzootske ataksije: dijagnostičko i prognostičko značenje. Vet. arhiv 87, 259-271, 2017.}

SAŽETAK

Dijagnostički, a posebice prognostički biomarkeri bitni su za kontrolu enzootske ataksije janjadi. Uzorci krvi uzeti su od 32 janjeta oboljela od enzootske ataksije i 15 zdrave janjadi kao kontrole. Razina hemoglobina (Hb) bila je određena u punoj krvi bolesne i zdrave janjadi. U serumu svih životinja bile su određene razine bakra $(\mathrm{Cu})$, ceruloplazmina $(\mathrm{Cp})$, selena (Se), malondialdehida (MDA), reduciranog glutationa (GSH), superoksid-dismutaze (SOD), srčanog troponina I (cTnI), kreatin-kinaze (CK) i aspartat-aminotransferaze (AST). Kliničkom je pretragom u bolesnih životinja bila ustanovljena anemija, snižene vrijednosti tjelesne temperature, povećane vrijednosti bila i disanja te neusklađeno kretanje. Razine malondialdehida, srčanog troponina I, kreatin-kinaze i aspartat-aminotransferaze bile su značajno povećane, dok su razine superoksiddismutaze i reduciranog glutationa bile značajno smanjene u bolesnih u odnosu na zdrave kontrolne životinje. Uspješno liječena janjad $(n=14)$ imala je niže razine srčanog troponina $I$, kreatin-kinaze i malondialdehida, ali više razine superoksid-dismutaze, bakra i ceruloplazmina u odnosu na neuspješno liječenu janjad. Međutim, kreatin-kinaza, superoksid-dismutaza i srčani troponin I pokazivali su veći stupanj točnosti u procjeni uspješnosti liječenja (uspješno u odnosu na neuspješno). Površina ispod krivulje iznosila je za kreatin-kinazu 0,97, za superoksid-dismutazu 0,94 te za srčani troponin I 0,92. Kreatin-kinaza i superoksid-dismutaza pokazivale su gotovo jednaku osjetljivost i specifičnost (osjetljivost $=94,44 \%$ odnosno 92,86\%, a specifičnost $=92,86 \%$ odnosno $93,75 \%$ ) što je bilo bolje od vrijednosti za troponin koje su iznosile za osjetljivost $88,89 \%$, a za specifičnost $85,71 \%$ ). Istraživanje je pokazalo da se kreatin-kinaza, superoksid-dismutaza i srčani troponin I mogu rabiti kao dijagnostički i prognostički biomarkeri u janjadi oboljele od enzootske ataksije.

Ključne riječi: janjad, srčani troponin, oksidacijski stres, bakar, elementi u tragovima 
